\title{
CARBIDE DISTRIBUTION BASED ON AUTOMATIC IMAGE ANALYSIS FOR CRYOGENICALLY TREATED TOOL STEELS
}

\author{
PRIKAZ PORAZDELITVE KARBIDNIH DELCEV V ORODNIH \\ JEKLIH, OBDELANIH S PODHLAJEVANJEM S POMOČJO \\ AVTOMATSKE ANALIZE SLIK
}

\author{
Pello Jimbert, Maider Iturrondobeitia, Julen Ibarretxe, \\ Roberto Fernandez-Martinez \\ University of the Basque Country (UPV/EHU), Faculty of Engineering, Paseo Rafael Moreno Pitxitxi, 348013, Bilbao, Spain \\ pello.jimbert@ehu.eus \\ Prejem rokopisa - received: 2016-07-14; sprejem za objavo - accepted for publication: 2016-09-29
}

doi:10.17222/mit.2016.165

\begin{abstract}
Particle distribution in steels has been widely reported in the scientific literature in terms of quantity and size of these particles. However, in these studies there is barely any information about the homogeneity or heterogeneity of the particle distribution. A cryogenically treated AISI A8 tool steel was compared against a conventionally treated one, not only in terms of the number and size of precipitated carbides, but also their distribution. Scanning-electron-microscopy images were automatically analyzed for this quantification. The results revealed an increase of $100 \%$ in the number of carbides and a reduction of $35 \%$ in the mean size of the precipitates for the cryogenically treated sample. The distribution of the particles - which turned out to be more homogeneous for the cryogenically treated sample - was characterized using the methodology described here, which applies automatic image analysis. These results may lead to an improvement in the wear resistance of a cryogenically treated AISI A8 alloy.

Keywords: particle distribution, automatic image analysis, tool steel, cryogenic treatment

Porazdelitev karbidnih delcev $\mathrm{v}$ jeklih glede na količino in velikost je obširno predstavljena v znanstveni literaturi. Toda te študije praktično ne podajajo informacije o homogenosti oz. heterogenosti porazdelitve teh delcev. Stevilo, velikost in porazdelitev karbidnih delcev v podhlajenem orodnem jeklu AISI A8 smo primerjali z vzorci konvencionalno pridobljenega jekla. Slike, posnete z vrstičnim elektronskim mikroskopom, smo za potrebe kvantifikacije avtomatsko analizirali. Rezultati kažejo $100 \%$ povečanje števila karbidnih delcev in zmanjšanje povprečne velikosti karbidnih precipitatov za $35 \% \mathrm{~V}$ podhlajenih vzorcih. Avtomatska analiza slik, razvita za potrebe te študije, podaja informacijo z izračunom porazdelitve delcev. Predstavljena študija nakazuje na bolj homogeno porazdelitev karbidnih delcev v podhlajenih vzorcih. Naši rezultati bi lahko pripomogli k izboljšanju obrabne odpornosti podhlajenih AISI A8 zlitin.

Ključne besede: porazdelitev delcev, avtomatska analiza slik, orodno jeklo, obdelava s podhlajevanjem
\end{abstract}

\section{INTRODUCTION}

There have been reports of carbide ${ }^{1}$ or oxide $^{2,3}$ precipitate quantity and size distribution in steels using image-processing software, even for particle sizes at the nanoscale 4 but not so many about the homogeneity of the distribution of these particles in the microstructure. Some studies show the distribution of these particles qualitatively using different techniques without a clear explanation of the methodology they followed. ${ }^{5}$ One of the shortcomings of this kind of particle-distribution calculation is the large amount of particles (and therefore images as well) needed to have a statistically representative quantification. In this work, an automatic methodology was developed to quantitatively analyze the microstructure of AISI A8 tool steels, by analyzing a statistically representative number of images of the bulk material.

\section{MATERIALS AND METHODOLOGY}

The methodology for characterizing the carbide distribution presented in this work was developed for the AISI A8 tool steel. It is a widely used tool-steel alloy that exhibits a high hardenability, good wear resistance, resistance to dynamic loading and toughness. Some of its applications include cold forming, blanking and bending dies, knurling tools, forming rolls, master dies and gages. Its chemical composition can be seen in Table $\mathbf{1}$.

Two samples of the AISI A8 were analyzed. Sample 1 underwent a conventional heat-treatment process of austenization at $1050{ }^{\circ} \mathrm{C}$ for $40 \mathrm{~min}$, air quenching and

Table 1: Chemical composition of the AISI A8 steel

\begin{tabular}{|c|c|c|c|c|c|c|c|}
\hline Material & $\mathrm{C}$ & $\mathrm{Mn}$ & $\mathrm{Si}$ & $\mathrm{Cr}$ & $\mathrm{Ni}$ & $\mathrm{Mo}$ & $\mathrm{W}$ \\
\hline AISI A8 & $0.5-0.6$ & 0.5 & $0.75-1.1$ & $4.75-5.5$ & 0.3 & $1.15-1.65$ & $1-1.5$ \\
\hline
\end{tabular}


two tempering processes of $90 \mathrm{~min}$ at $500{ }^{\circ} \mathrm{C}$. Sample 2 underwent an additional final-cyclic cryogenic treatment of 6 cycles from $-73{ }^{\circ} \mathrm{C}$ to $-172{ }^{\circ} \mathrm{C}$ taking $15 \mathrm{~h}$ after the conventional heat treatment. The cryogenic treatment is applied to different tool steels for the improvement of the wear resistance and this improvement is related to the precipitation of carbides. ${ }^{6}$ The influence of the cryogenic treatment on the precipitation of carbides of the AISI A8 medium-alloy tool steel was investigated for the first time in this work.

Scanning electron microscope (SEM) images were used to calculate the carbide distribution and microstructural parameters such as the number of particles, their mean sizes and the total area. The images were acquired with a JEOL JSM-6400F SEM model at $10 \mathrm{KV}$ and a $500 \times$ magnification. The pixel size was $9.2 \mathrm{pixel} / \mu \mathrm{m}$. Ten images of $200 \mu \mathrm{m} \times 200 \mu \mathrm{m}$, acquired in different areas, were analyzed for each sample. Considering the resulting average sizes and their corresponding deviations (Figure 1), the number of analyzed particles (900 for sample 1 and 1800 for sample 2) is sufficient to statistically ensure that the average values are accurate within $\pm 0.1 \mu \mathrm{m}$ at a $95 \%$ confidence.

The automatic image analysis was carried out using Fiji. ${ }^{7}$ First of all, the images were binarized using the Auto Local Threshold plug-in with different algorithms (Bernsen, Mean, MidGrey, Niblack and Sauvola). The Sauvola algorithm was chosen since it gave the most
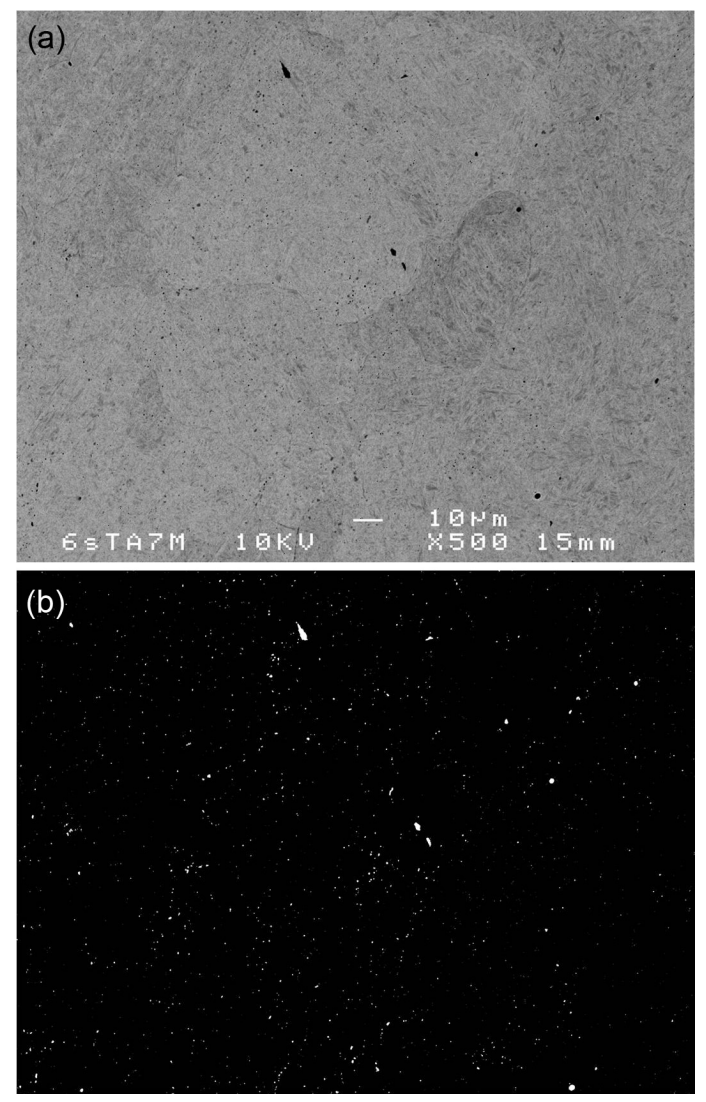

Figure 1: a) Original SEM image and b) binarized image suitable binarization of the carbides over the martensitic matrix, based on our experience in this field as can be seen in Figure 1. The SEM images were then automatically analyzed using the Sauvola algorithm and the following information for the carbides was obtained: centroid positions, the number of particles and sizes. To calculate the distribution of the carbides, their centroids were used, computing the distances to the four closest neighbors and their averages using an in-house made script in Matlab. ${ }^{8}$

\section{RESULTS AND DISCUSSION}

The density of carbide particles increases for the cryogenically treated sample (sample 2) from 0.026 particles $/ \mu \mathrm{m}^{2}$ to 0.054 particles $/ \mu \mathrm{m}^{2}$. This indicates an increase of around $100 \%$ in the number of particles. This result is in good agreement with the results obtained for different tool steels, which show an increase in the number of carbides when they are cryogenically treated. ${ }^{9}$ This increase in the number of carbides is related, in the literature, with an increase in the wear resistance. ${ }^{10}$ The observed effect is very promising regarding the possibility to include the cryogenic treatment of the AISI A8 tool steel when used for severe friction applications.

Also, the mean particle length decreases from $6.2 \pm 1.3$ to $4.1 \pm 1.5 \mu \mathrm{m}$. This result is in concordance with those reported for other tool steels after being cryogenically treated. ${ }^{10} \mathrm{D}$. Das et al. ${ }^{11}$ concluded that the cryogenic treatment creates new carbide segregates during the cooling and this segregates grow during the heating from the cryogenic temperature to the ambient temperature creating small secondary carbides. The small size of these new carbides reduces the mean size of the precipitates present in the material.

Regarding the distribution of the particles (Figure 2), the distribution of the newly precipitated carbides is more homogeneous for sample 2 . The percentage of the area occupied by the carbides increases from $0.4 \%$ for the conventionally treated sample to $0.6 \%$ for the cryogenically treated sample. The final microstructure of the

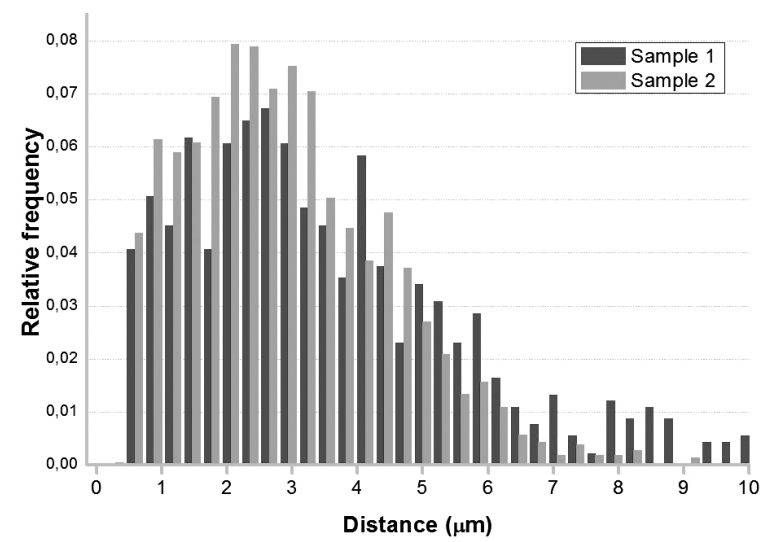

Figure 2: Carbide distribution for the conventionally treated (sample 1) and for the cryogenically treated (sample 2) samples 
cryogenically treated sample has more carbides, they cover a bigger area and they are more homogeneously distributed than in the conventionally treated one.

\section{CONCLUSION}

The microstructure is quantitatively measured using a methodology based on automatic image analysis. The methodology used for the carbide-distribution calculation developed in this study was satisfactorily applied to tool steels and the obtained results support the suitability of this methodology.

The distribution of the carbides precipitated during the cryogenic treatment of the AISI A8 steel is more homogenous, indicating a more homogeneous final microstructure.

The AISI A8 tool steel showed a potential to be cryogenically treated since there is an increase in the number of precipitated carbides, reducing their mean sizes and covering a $43 \%$ larger area, which may lead to an increase in the wear resistance.

\section{Acknowledgements}

This work was supported by the Department of Industry, Innovation, Trade and Tourism of the Basque Country Government through the S-PE12UN080 SAIOTEK project. The authors thank for the technical and human support provided by SGIker of UPV/EHU and European funding (ERDF and ESF).

\section{REFERENCES}

${ }^{1}$ C. Revilla, B. López, J. M. Rodriguez Ibabe, Carbide size refinement by controlling the heating rate during induction tempering in a low alloy steel, Materials and Design, 62 (2014), 296-304, doi:10.1016/ j.matdes.2014.05.053

${ }^{2}$ S. F. Li , Z. J. Zhou, P. H. Wang, H.Y. Sun, M. Wang, G. M. Zhang, Long-term thermal-aging stability of a $16 \mathrm{Cr}$-oxide dispersion strengthened ferritic steel at $973 \mathrm{~K}$, Materials and Design, 90 (2016), 318-329, doi:10.1016/j.matdes.2015.10.138

${ }^{3}$ M. Nagini, R. Vijay, M. Ramakrishna, A.V. Reddy, G. Sundararajan, Influence of the duration of high energy ball milling on the microstructure and mechanical properties of a $9 \mathrm{Cr}$ oxide dispersion strengthened ferritic-martensitic steel, Materials Science \& Engineering A, 620 (2015), 490-499, doi:10.1016/j.msea.2014.10.050

${ }^{4}$ C. Solenthaler, M. Ramesh, P. J. Uggowitzer, R. Spolenak, Precipitation strengthening of Nb-stabilized TP 347 austenitic steel by a dispersion of secondary $\mathrm{Nb}(\mathrm{C}, \mathrm{N})$ formed upon a short-term hardening heat treatment, Materials Science \& Engineering A, 647 (2015), 294-302, doi:10.1016/j.msea.2015.09.028

${ }^{5} \mathrm{~S}$. Amirkhanlou, B. Niroumand, Effects of reinforcement distribution on low and high temperature tensile properties of $\mathrm{Al} 356 / \mathrm{SiCp}$ cast composites produced by a novel reinforcement dispersion technique, Materials Science and Engineering A, 528 (2011), 7186-7195, doi:10.1016/j.msea.2011.06.013

${ }^{6}$ P. Baldissera, C. Delprete, Deep cryogenic treatment: a bibliographic review, The Open Mechanical Engineering Journal, 2 (2008), 1-11, doi:10.2174/1874155X00802010001

${ }^{7}$ J. Schindelin, I. Arganda-Carreras, E. Frise, V. Kaynig, M. Longair, T. Pietzsch, S. Preibisch, C. Rueden, S. Saalfeld, B. Schmid, J.-Y. Tinevez, D. J. White, V. Hartenstein, K. Eliceiri, P. Tomancak, A. Cardona, Fiji: an open-source platform for biological-image analysis, Nat. Methods, 9 (2012) 7, 676-82, doi:10.1038/nmeth.2019

${ }^{8}$ MATLAB Release 2014b, The MathWorks, Inc., Natick, Massachusetts, USA

${ }^{9}$ J. Y. Huang, Y. T. Zhu, X. Z. Liao, I. J. Beyerlein, M. A. Bourke, T. E. Mitchell, Microstructure of cryogenically treated M2 tool steel, Materials Science and Engineering A, 339 (2003), 241-244, doi:10.1016/S0921-5093(02)00165-X

${ }^{10} \mathrm{~S}$. Akincioğlu, H. Gökkaya, I. Uygur, A review of cryogenic treatment on cutting tools, Int. J. Adv. Manuf. Technol, 78 (2015), 1609-1627, doi:10.1007/s00170-014-6755-x

${ }^{11}$ D. Das, A. K. Dutta, K. K. Ray, Sub-zero treatments of AISI D2 steel: Part I. Microstructure and hardness, Materials Science and Engineering A, 527 (2010), 2182-2193, doi:10.1016/j.msea.2009. 10.070 